\title{
P-T PATH FLUID EVOLUTION IN THE GROSS SPITZKOPPE GRANITE STOCK, NAMIBIA
}

\author{
STEPHEN FRINDT AND MATTI POUTIAINEN
}

FRINDT, STEPHEN and POUTIAINEN, MATTI 2002. P-T path fluid evolution in the Gross Spitzkoppe granite stock, Namibia. Bulletin of the Geological Society of Finland 74, Parts 1-2, 103-114.

The Gross Spitzkoppe granite stock (GSS) is a zoned $30 \mathrm{~km}^{2}$ epizonal intrusion that consists of three main granites: 1$)$ medium-grained biotite granite (marginal), 2) a coarse-grained biotite granite, and 3) a central, porphyritic granite. The stock contains pegmatites as banded marginal stockscheiders and isolated pockets composed of large alkali feldspar and quartz, dark mica, interstitial fluorite, and euhedral topaz and beryl crystals. In the porphyritic granite there are local wolframite-bearing greisens and hydrothermal fluorite and topaz-rich veins.

Fluid inclusion studies were conducted on: 1) topaz and quartz crystals from the marginal stockscheider; 2) quartz, topaz, fluorite and beryl crystals from isolated pegmatites; 3 ) topaz from a miarolitic pegmatite; 4) beryl and quartz veins from greisenized porphyritic granite; and 5) fluorite from a late fluorite vein in the coarse-grained biotite granite. Preliminary data indicate the presence of three compositionally distinct primary and pseudosecondary inclusion types that are of late magmatic-hydrothermal origin.

Type 1 . Low salinity $(0-10$ eq. wt $\% \mathrm{NaCl}) \mathrm{H}_{2} \mathrm{O}\left( \pm \mathrm{CO}_{2}\right)$ inclusions that homogenize to the liquid phase in the temperature range of 300 to $550^{\circ} \mathrm{C}$. These inclusions are from quartz, topaz and beryl. Inclusions in fluorite from the fluorite vein homogenize at $\sim 170^{\circ} \mathrm{C}$ and have a salinity of ca. $1-2$ eq. wt $\% \mathrm{NaCl}$.

Type 2. Saline (25-30 eq. wt $\% \mathrm{NaCl})$ halite-bearing $\mathrm{H}_{2} \mathrm{O}\left( \pm \mathrm{CO}_{2}\right)$ inclusions that homogenize to the liquid phase in the temperature range of 300 to $400^{\circ} \mathrm{C}$. These inclusions are from quartz.

Type 3. Low salinity $(0-3$ eq. wt $\% \mathrm{NaCl}) \mathrm{H}_{2} \mathrm{O}-\mathrm{CO}_{2}$ inclusions that homogenize to vapor phase in the temperature range of 330 to $550^{\circ} \mathrm{C}$. These inclusions are from quartz and topaz.

Hydrothermal fluids from greisen minerals are represented by type 1 and type $2 \mathrm{H}_{2} \mathrm{O}$ inclusions. They are predominantly of low salinity $(\sim 8$ eq. wt $\% \mathrm{NaCl})$ and homogenize to the liquid phase in the temperature range of 300 to $500^{\circ} \mathrm{C}$. Isochores for contemporaneous type 2 and type 3 inclusions with homogenization temperature range of 330 to $400^{\circ} \mathrm{C}$ indicate a maximum trapping pressure of about 900 bar for the marginal stockscheider.

Key words: fluid inclusions, homogenization temperature, trapping pressure, retrograde boiling, halite, greisen, pegmatite, granite, Namibia

Stephen Frindt and Matti Poutiainen: Department of Geology, Box 64, FIN00014 University of Helsinki, Finland.

E-mails: stephen.frindt@helsinki.fi_matti.poutiainen@helsinki.fi 


\section{INTRODUCTION}

The northeast-trending Late Precambrian Damara Orogen of Namibia has been recognized as having great potential in terms of base metal mineralization (Steven 1993). Extensive geochemical and to a lesser extent, fluid inclusion studies have been conducted on several ore-bearing ( $\mathrm{Sn}, \mathrm{W}, \mathrm{Ta}$ and $\mathrm{Nb}$ ) late-orogenic suites, dominated by leucogranites and pegmatites (Ollila 1987, Wagener 1989, Steven 1993), and on hydrothermal and greisen-style quartz-cassiterite-wolframite deposits associated with anorogenic igneous complexes (e.g. Kranzberg Mine of the Erongo Volcanic Complex) within the Damaraland igneous province (Pirajno \& Schlögel 1987).

The Gross Spitzkoppe granite stock (GSS) is situated within the North Central Zone of the Damara orogenic belt, defined by Martin (1965). This zone, also referred to as the Southern Tin Zone, consists of Proterozoic metasedimentary rocks that are intruded by late- to post-orogenic
Damara granites and $\mathrm{Sn}-\mathrm{W}$ bearing pegmatite dikes (Fig. 1). The GSS belongs to a group of 21 Damaraland volcanic-plutonic complexes that were emplaced during widespread Cretaceous anorogenic magmatism associated with the opening of the South Atlantic Ocean. The stock is devoid of any significant $\mathrm{Sn}$ and $\mathrm{W}$ mineralization despite its evolved geochemical composition and watersaturated residual phases (i.e. miarolitic cavities and hydrothermal veins). Only minor occurrences of disseminated columbite and wolframite are associated with greisen bodies of the central porphyritic granite of the stock (Frindt \& Poutiainen 1999).

The main aim of this paper is to present the results of fluid inclusion studies carried out on several pegmatite, hydrothermal and greisen minerals. Results of this study allow us to determine the evolution of fluids and to place some constraints on P-V-T-X conditions of late- to post-magmatic fluids.

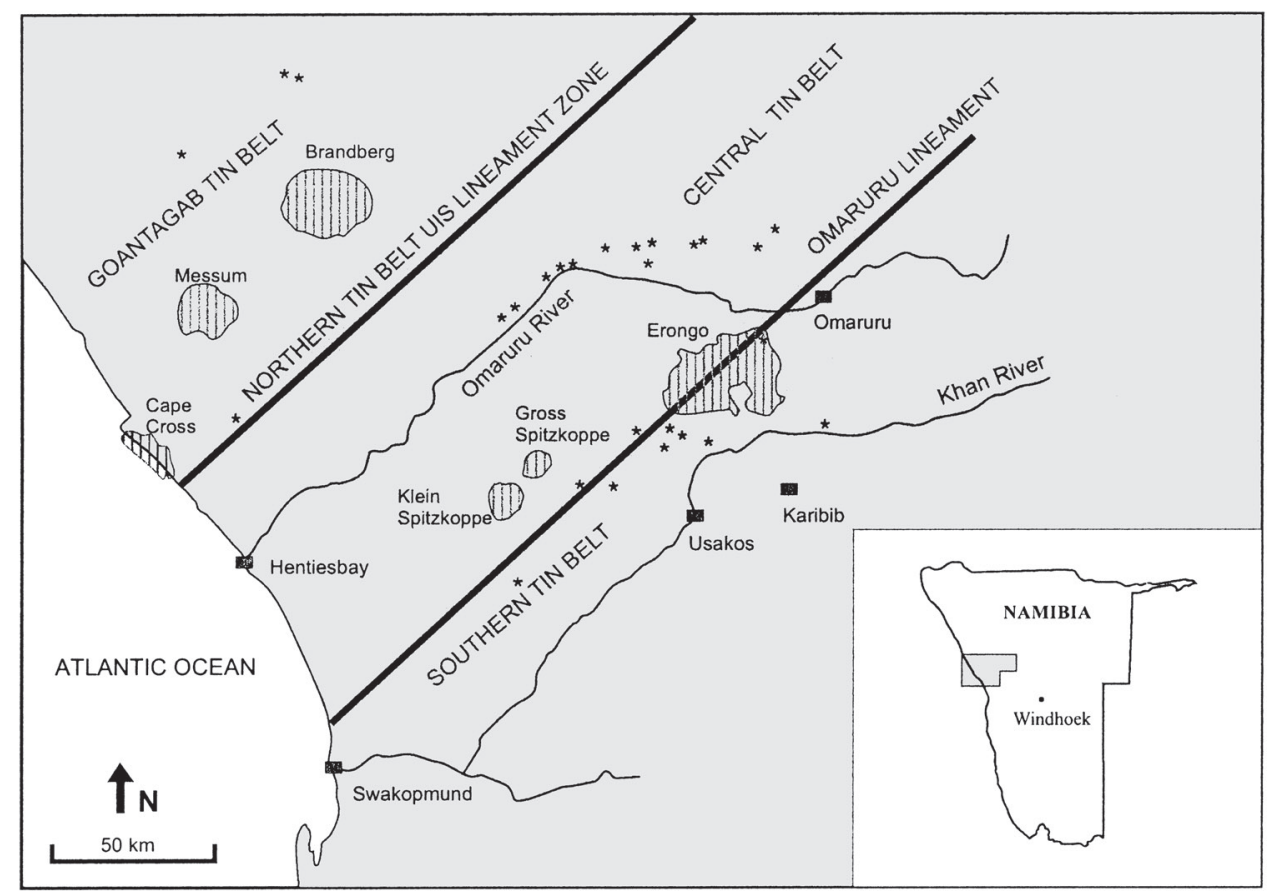

Fig. 1. Generalized geological map of western Namibia, showing the location of some Mesozoic anorogenic complexes (vertical lines) and occurrences of Damara $\mathrm{Sn}, \mathrm{Li}$, Be and $\mathrm{Nb}$-Ta mineralized pegmatites (stars), modified after Ollila (1987). 


\section{GEOLOGY OF THE GROSS SPITZKOPPE}

\section{Geological setting}

The GSS is a well exposed, roughly circular intrusion that occupies an area of $\sim 30 \mathrm{~km}^{2}$ and intruded into the surrounding country rock - Damara S-type granite, quartz biotite schists of the Kuiseb Formation and graphite-bearing marble of the Karibib Formation. The stock consists essentially of three texturally distinct monzogranites, which are mineralogically and geochemically very similar. The granites from the margin to the core of the stock are: medium-grained biotite granite, coarse-grained biotite granite, and porphyritic granite (Fig. 2). The occurrences of aplite and porphyritic dikes, as well as pegmatites represent crystallized residual granite melts. Petrographic and geochemical studies on the GSS granites have been done by Frindt (1997) and Frindt and Haapala (1999). In brief, the granites have A-type characteristics and plot in the field of within plate granites (WPG) in discrimination diagrams of Pearce et al. (1984). The granites are weakly peraluminous, are characterized by high silica (up to 78 wt $\%$ ), $\mathrm{F}$ (up to $1.2 \mathrm{wt} \%$ ), $\mathrm{Rb}$ (up to $800 \mathrm{ppm}$ ), and $\mathrm{Nb}$ (up to $120 \mathrm{ppm}$ ), and low $\mathrm{MgO}(<0.05 \mathrm{wt} \%)$, $\mathrm{CaO}(<0.1 \mathrm{wt} \%), \mathrm{P}(<0.1 \mathrm{wt} \%)$, and $\mathrm{B}$ (below detection limit) content. The granites are highly differentiated with high $\mathrm{Rb} / \mathrm{Sr}$ and $\mathrm{Rb} / \mathrm{Ba}$ ratios. It has been proposed that the GSS granites are derived by small degrees of partial melting of a melt-depleted crustal source rock (Trumbull et al. 2000).

The granites are composed in roughly equal proportions of perthitic alkali feldspar (30-40\%), quartz (30-38\%), plagioclase ( $\left.\mathrm{An}_{1-15}\right),(16-25 \%)$, and iron-rich biotite (siderophyllite - annite) $(<10 \%)$. Accessory minerals include fluorite, topaz, zircon, thorite, monazite, magnetite, columbite, and niobian rutile. It is noteworthy that analyzed biotites, which are a late crystallizing mineral, contain high Sn contents of up to 200 ppm (Frindt 2000).

The stock has a shallow level of emplacement, which can be inferred from the presence of miarolitic cavities, aplite dikes and undercooling textures (plumose alkali feldspar with quartz intergrowths).

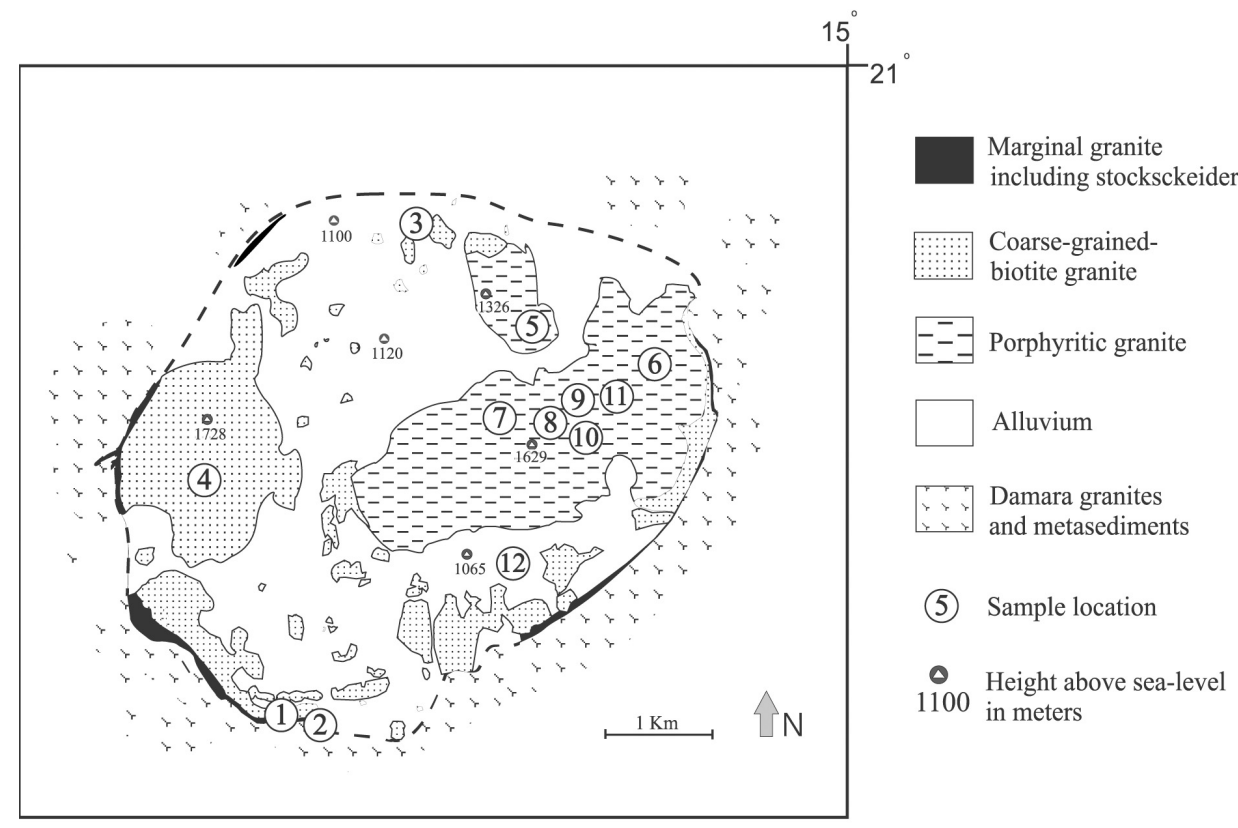

Fig. 2. Simplified geological map of the Gross Spitzkoppe granite stock (Frindt 1997). Sample locations are denoted by numbered circles. 1- quartz, 2-topaz, 3- beryl, 4- beryl, 5-miarolitic topaz, 6-fluorite, 7-quartz, 8topaz, 9- quartz, 10-beryl (greisen), 11-quartz (greisen) and 12- hydrothermal fluorite. 


\section{Pegmatite}

The stock contains pegmatites as banded marginal stockscheiders up to 10 meters in width and as isolated pockets up to 2 meters in diameter, which are composed of large alkali feldspar and quartz crystals, dark mica, interstitial fluorite, and euhedral topaz and beryl crystals. Ce-allanite, calcite, goethite (pseudomorph after carbonate), and fergusonite are accessory minerals in some of the studied pegmatites.

\section{Hydrothermal alteration}

Petrography of the granites indicate a progressive increase in the extent of alteration, from the medium-grained granite and coarse-grained granites to the porphyritic granite; this is due to an increase of fluid activity. Hydrothermal alteration in the stock is largely restricted to the central, porphyritic granite where hydrothermal veins and pervasive greisen bodies are found. In the case of the medium-grained granite and coarse-grained granites, post-magmatic fluids are responsible for: i) partial alteration of plagioclase cores to sericite, topaz and fluorite; ii) development of perthitic replacement textures (i.e. chess board albite); and iii) growth of secondary albite rims along feldspar margins. Quartz phenocrysts contain sparse secondary fluid inclusions, which occur along annealed microfractures. Biotite is partially altered to white mica, chlorite and in places to fibrous sericite. Extensive alteration of biotite to chlorite occur in proximity to hydrothermal veins and pegmatite bodies.

\section{Greisen formation}

Several pervasive greisen bodies have been identified in the porphyritic granite of the stock. The largest of the greisens occupies an area of approximately $200 \mathrm{~m}^{2}$. Typically, the greisens consist of quartz, topaz, fluorite, sericite, and white mica. Identified accessory minerals include magnetite, disseminated wolframite and columbite crystals. The greisens are associated with a number of topaz, beryl, quartz and hematite-goethite veinlets, which appear to have random orientation. It is believed that magmatic and post-magmatic fluids channeled via these fractures, leading to the pervasive greisenization of the porphyritic granite. One sample of the greisenized granite was chemically analyzed; it shows elevated concentrations of W (4440 ppm), Nb (210 ppm), Be (114 ppm) and to a lesser extent $\mathrm{Sn}$ (37 ppm) and $\mathrm{Cu}(53$ ppm) when compared to the unaltered porphyritic granite (Frindt 2000).

\section{SAMPLE SELECTION}

Double polished thick sections $(250 \mu \mathrm{m})$ were prepared from idiomorphic crystals sampled from the marginal stockscheider (quartz, topaz, beryl), internal isolated pegmatite pockets (quartz, topaz, beryl, fluorite), greisen veins (beryl, quartz), miarolitic cavity (topaz), and a late (hydrothermal) fluorite vein ( $2 \mathrm{~m}$ in width) of the Gross Spitzkoppe granite stock. With exception to greisen minerals, which contain abundant secondary fluid inclusions, all the other crystals studied show relatively minor evidence of secondary fluid overprinting.

\section{ANALYTICAL TECHNIQUES}

Microthermometric studies of fluid inclusions were performed on 12 samples using a Linkam THMS 600 programmable heating/freezing stage attached to a transmitting light microscope equipped with a Leitz UTK 50/0.63 objective. The stage was calibrated with synthetic fluid inclusions (cf. Sterner \& Bodnar 1984). Salinity of the fluid inclusions was calculated using halite dissolution temperatures (Linke 1965) and final ice melting temperatures (Bodnar 1993). Fluid densities were calculated using Linkam P-V-T-X software.

The instrument used in acoustic decrepitometry is a BGS Model 105 (Burlinson 1988). Whole rock samples were crushed and sieved to $250-300$ $\mu \mathrm{m}$. Mineral samples weighing $0.5 \mathrm{~g}$ were analyzed. The temperature range for runs was set to 100 to $620^{\circ} \mathrm{C}$ and heating rate to $20^{\circ} \mathrm{C} \mathrm{min}{ }^{-1}$. The background noise level was determined using a pure quartz sample of optical quality. 


\section{RESULTS}

\section{Decrepitometry}

To estimate the relative amount of fluid present in each of the granites, five representative wholerock samples were analyzed with fluid inclusion decrepitometry. Decrepitometry involves measuring the temperature distribution at which fluid inclusions decrepitate during heating (cf. Scott 1948). 1) An analysis of the medium-grained granite suggests that a large number of fluid inclusions decrepitated in the temperature range of 380 to $450{ }^{\circ} \mathrm{C}$ with a distinct peak centered at $430^{\circ} \mathrm{C}$ (Fig. 3). 2) An analysis of the coarse-grained biotite granite shows a relatively broad low-intensity peak $(<1000$ decrepitations $)$ at temperatures between 400 and $500^{\circ}$ C. 3 ) An analysis of the porphyritic granite shows two well-developed high-temperature peaks at $480^{\circ} \mathrm{C}$ and $520^{\circ} \mathrm{C}$. 4) An analysis of the greisen milky-quartz vein, which contains abundant secondary fluid inclusions, shows a dis- tinct high-temperature peak at $460^{\circ} \mathrm{C}$ and a pronounced low temperature $\left(<350^{\circ} \mathrm{C}\right)$ skew in the decrepigram, which signifies the presence of carbonaceous fluid inclusions (cf. Burlinson 1991, Mavrogenes et al. 1995). 5) An analysis of the Damara granite, which represents the surrounding country rock, shows a very low decrepitation response of fluid inclusions compared to the granites of the stock, indicating apparent dryness of the rock. This apparent dryness of the Damara granite is confirmed by the absence of deuteric and meteoric alteration (cf. Steven 1993).

The granite samples measured show a progressive increase in water content (i.e., number of fluid inclusions) from the medium-grained granite to the core of the stock, which is locally water saturated. In addition, there is a trend towards a gradual temperature decrease from the porphyritic granite in the central part of the stock to the coarsegrained biotite granite and medium-grained granite in the periphery of the stock.

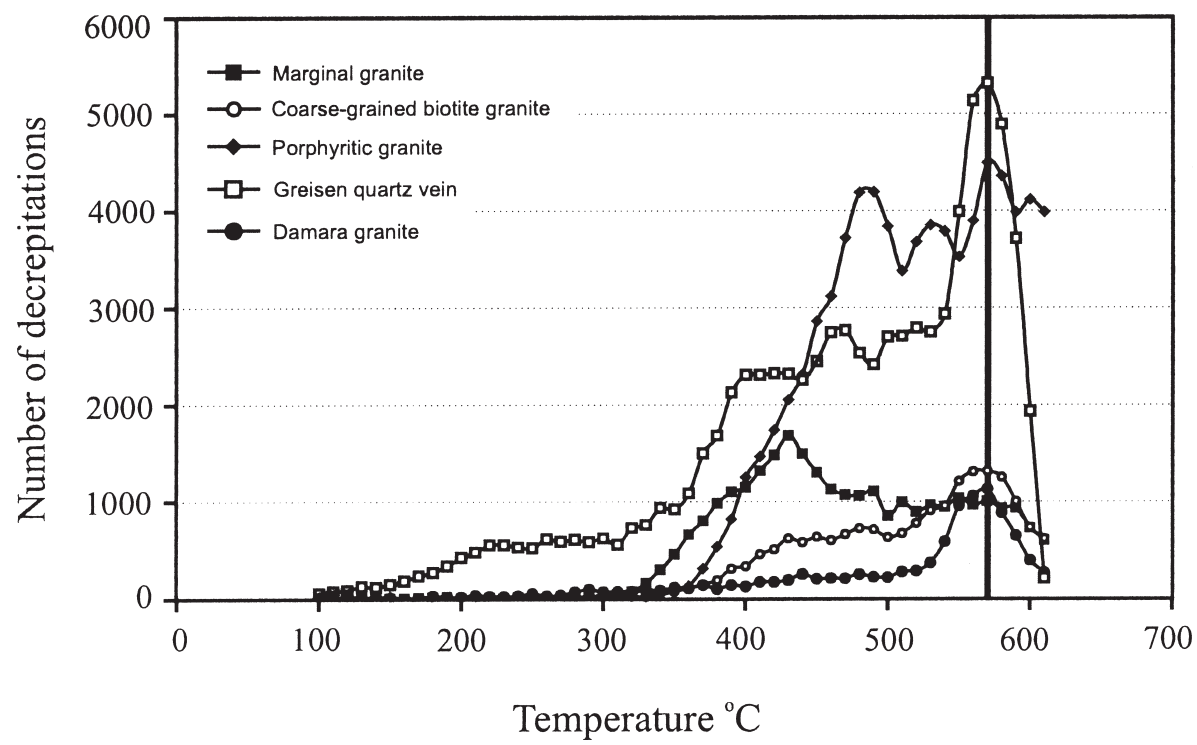

Fig. 3. Decrepigrams of representative granite samples of the Gross Spitzkoppe stock. An increase in the number of decrepitations from the medium-grained granite to the porphyritic granite can be observed. A sample of greisen quartz vein that contains wolframite and columbite crystals indicates the presence of low-temperature carbonaceous inclusions. A sample of the Damara granite is included for comparison. See the text for further explanation. Note the quartz inversion peak at $573^{\circ} \mathrm{C}$, especially prominent for samples of a greisen quartz vein and porphyritic granite. 

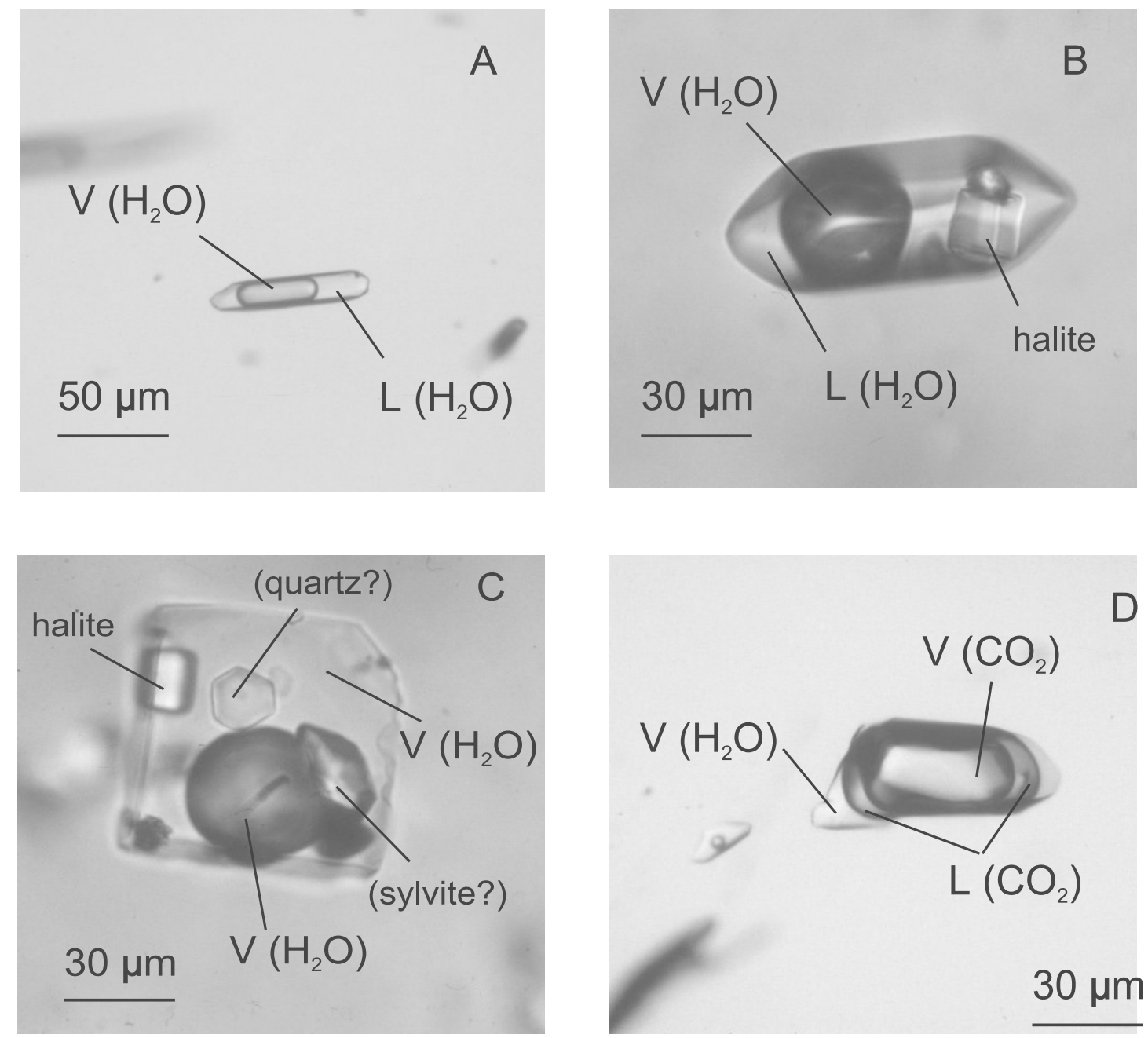
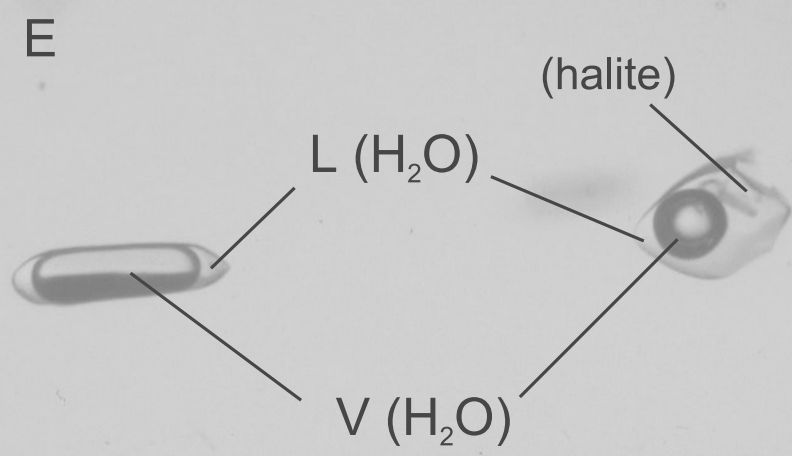

$50 \mu \mathrm{m}$
Fig. 4. Photomicrographs (A-E) of fluid inclusions from minerals of the Gross Spitzkoppe stock. A). Tubular shaped $\mathrm{H}_{2} \mathrm{O}\left( \pm \mathrm{CO}_{2}\right)$ inclusion in quartz from the marginal stockscheider. B). Negative crystal shaped halite-bearing $\mathrm{H}_{2} \mathrm{O}\left( \pm \mathrm{CO}_{2}\right)$ inclusion from quartz of the marginal stockscheider. C). Multiphase halite-bearing $\mathrm{H}_{2} \mathrm{O}\left( \pm \mathrm{CO}_{2}\right)$ fluid inclusion in fluorite from an isolated pegmatite. $D$ ). $\mathrm{H}_{2} \mathrm{O}-\mathrm{CO}_{2}$ inclusion with a distinct liquid $\mathrm{CO}_{2}$ phase from quartz of the marginal stockscheider. E). Coeval halitebearing $\mathrm{H}_{2} \mathrm{O}\left( \pm \mathrm{CO}_{2}\right)$ and $\mathrm{H}_{2} \mathrm{O}\left( \pm \mathrm{CO}_{2}\right)$ inclusions in quartz from the marginal stockscheider. 


\section{Classification, description and microther- mometry of fluid inclusions}

Three types of fluid inclusions were distinguished on the basis of morphology, volume percentage of vapor estimated at room temperature, mode of homogenization (liquid/vapor/critical), and the presence of daughter minerals. All the fluid inclusions studied are classified as primary, pseudosecondary or secondary according to the terminology of Roedder (1981). Microthermometric data are summarized in Table 1 and Fig. 4.

1. $\mathrm{H}_{2} \mathrm{O}\left( \pm \mathrm{CO}_{2}\right)$ inclusions. This is the most common fluid inclusion type observed in beryl, topaz and quartz crystals (marginal stockscheider) (Fig. 5a). They are low salinity (0-15 eq. wt $\%$ $\mathrm{NaCl}$ ) inclusions characterized by either tubular (beryl) or negative (quartz and topaz) crystals shapes measuring $\sim 10-50 \mu \mathrm{m}$ in the longest dimension. The volumetric proportion of the vapor phase is below $60 \mathrm{vol} \%$. Homogenization of the inclusions takes place at temperatures of 300 to $550^{\circ} \mathrm{C}$. However, some inclusions in quartz and topaz show critical homogenization at approximately $470^{\circ} \mathrm{C}$. Similar $\mathrm{H}_{2} \mathrm{O}\left( \pm \mathrm{CO}_{2}\right)$ inclusions occur in a beryl crystal from a greisen vein. A late fluorite vein in the coarse-grained biotite granite hosts $\mathrm{H}_{2} \mathrm{O}$ inclusions, which homogenize into the liquid phase at temperatures below $200^{\circ} \mathrm{C}$ and have salinity of ca. 1-2 eq. wt $\% \mathrm{NaCl}$.

2. Halite-bearing $\mathrm{H}_{2} \mathrm{O}\left( \pm \mathrm{CO}_{2}\right)$ inclusions. This inclusion type was observed in quartz crystals from isolated pegmatites in the porphyritic granite and from quartz in the marginal stockscheider. They have regular morphology (usually negative crystal shape) and are 30-100 $\mu \mathrm{m}$ in the longest dimension. Vapor bubble occupies less than 50 vol\%. Homogenization of the inclusions into the liquid phase occurs in the temperature range of 300 to $400^{\circ} \mathrm{C}$. Average halite dissolution temperatures of about $200^{\circ} \mathrm{C}$ suggest salinities around 30 wt $\% \mathrm{NaCl}$. The inclusions contain, in addition to halite and sylvite, several unidentified daughter minerals (Fig. 5b). The presence of silicate minerals are considered as phases accidentally trapped during the growth of the crystal (Fig. 5c). Vapor phase of type 1 and type $2 \mathrm{H}_{2} \mathrm{O}$ inclusions contain some dissolved $\mathrm{CO}_{2}$, as suggested by minor

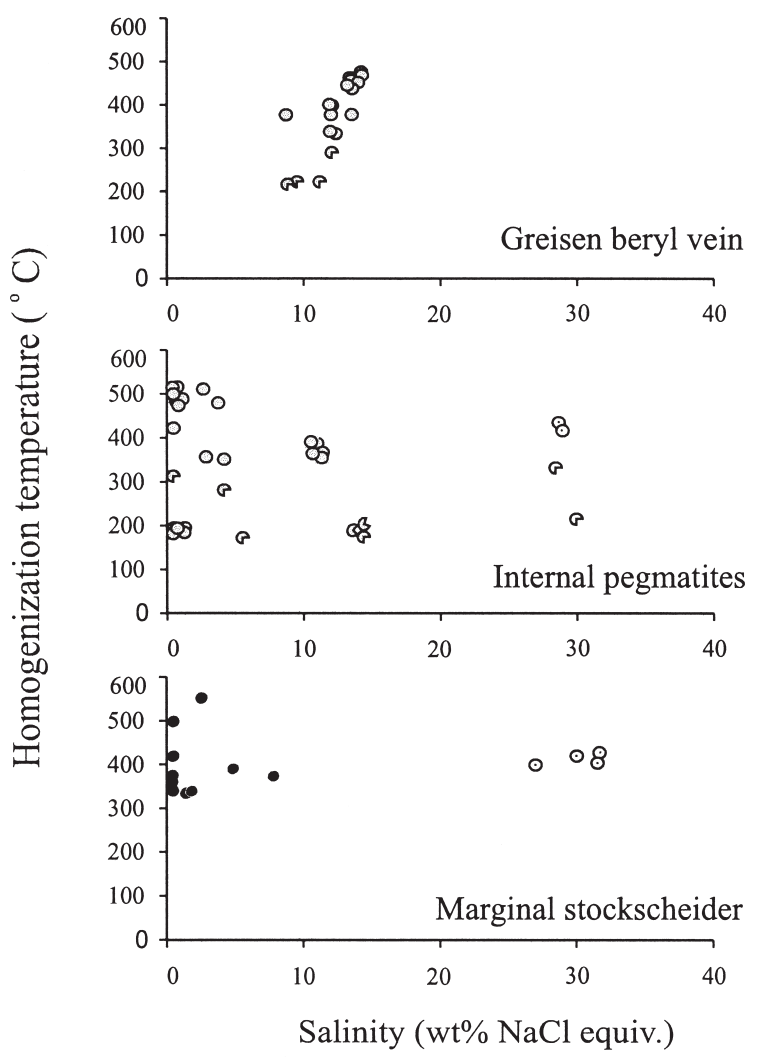

Fig. 5. Homogenization temperature versus salinity of fluid inclusions from minerals of the Gross Spitzkoppe stock. Quartz and topaz crystals from the marginal stockscheider contain type 2 halite-bearing $\mathrm{H}_{2} \mathrm{O}( \pm$ $\mathrm{CO}_{2}$ ) and type $3 \mathrm{H}_{2} \mathrm{O}-\mathrm{CO}_{2}$ inclusions. Quartz, topaz. and beryl crystals from the internal pegmatites contain type $1 \mathrm{H}_{2} \mathrm{O}\left( \pm \mathrm{CO}_{2}\right)$ and type 2 halite-bearing $\mathrm{H}_{2} \mathrm{O}$ $\left( \pm \mathrm{CO}_{2}\right)$ inclusions. Beryl crystal from greisen contains type $1 \mathrm{H}_{2} \mathrm{O}\left( \pm \mathrm{CO}_{2}\right)$ inclusions.

clathrate formation around the gas bubble during freezing.

3. $\mathrm{H}_{2} \mathrm{O}-\mathrm{CO}_{2}$ inclusions. This inclusion type occurs in topaz, quartz and beryl crystals from the marginal stockscheider and in topaz from a miarolitic cavity within the porphyritic granite. Mixed $\mathrm{H}_{2} \mathrm{O}-\mathrm{CO}_{2}$ inclusions have low salinity (08 eq. wt $\% \mathrm{NaCl})$ as indicated by clathrate melt- 
Table 1. Microthermometric data $\left(T{ }^{\circ} \mathrm{C}\right)$ of fluid inclusions in pegmatite, hydrothermal and greisen minerals from the Gross Spitzkoppe granite stock

\begin{tabular}{lllllll}
\hline mineral & location & class & type & number & Th-(L/V)* & Te (ice)* \\
\hline Topaz \#3 & $\mathrm{pg}$ & primary & $\mathrm{H}_{2} \mathrm{O}$ & 10 & $315 / 475(\mathrm{~L})$ & $-21.3 /-21.6$ \\
Quartz \#2 & $\mathrm{pg}$ & pseud sec. & $\mathrm{H}_{2} \mathrm{O}$ & 12 & $124 / 315(\mathrm{~L})$ & $-24 /-32$ \\
Quartz \#2 & $\mathrm{pg}$ & pseud sec. & halite- $\mathrm{H}_{2} \mathrm{O}$ & 4 & $175 / 342(\mathrm{~L})$ & \\
Quartz \#2 & $\mathrm{pg}$ & secondary & $\mathrm{H}_{2} \mathrm{O}$ & 3 & $140 / 155(\mathrm{~L})$ & -32 \\
Quartz \#1 & $\mathrm{pg}$ & primary & halite- $\mathrm{H}_{2} \mathrm{O}$ & 7 & $364 / 408(\mathrm{~L})$ & $-21.7 /-21$ \\
Quartz \#1 & $\mathrm{pg}$ & pseud sec. & halite- $\mathrm{H}_{2} \mathrm{O}$ & 4 & $270 / 392(\mathrm{~L})$ & -30 \\
Quartz \#1 & $\mathrm{pg}$ & secondary & $\mathrm{H}_{2} \mathrm{O}$ & 1 & $130(\mathrm{~L})$ & \\
Fluorite & $\mathrm{pg}$ & primary & $\mathrm{H}_{2} \mathrm{O}$ & 5 & $300 / 411(\mathrm{~L})$ & $-23 / 26$ \\
Topaz & $\mathrm{mp}$ & primary & $\mathrm{H}_{2} \mathrm{O}$ & 4 & $436 / 467(\mathrm{~L})$ & $-21 /-23$ \\
Topaz & $\mathrm{mp}$ & pseud sec. & $\mathrm{H}_{2} \mathrm{O}-\mathrm{CO}_{2}$ & 9 & $438 / 446(\mathrm{~V})$ & \\
Topaz & $\mathrm{mp}$ & secondary & $\mathrm{H}_{2} \mathrm{O}$ & 4 & $127 / 172(\mathrm{~L})$ & \\
Quartz \#2 & $\mathrm{mp}$ & primary & $\mathrm{H}_{2} \mathrm{O}-\mathrm{CO}_{2}$ & 3 & $330 / 385(\mathrm{~V})$ & $-5.2 /-23$ \\
Quartz \#2 & $\mathrm{mp}$ & primary & $\mathrm{H}_{2} \mathrm{O}-\mathrm{CO}_{2}$ & 6 & $404 / 427(\mathrm{~V})$ & -52 \\
Topaz & $\mathrm{mp}$ & primary & $\mathrm{H}_{2} \mathrm{O}-\mathrm{CO}_{2}$ & 5 & & \\
Beryl & grs & pseud sec. & $\mathrm{H}_{2} \mathrm{O}$ & 21 & $329 / 470(\mathrm{~L})$ & $-21 /-23.6$ \\
Beryl & grs & secondary & $\mathrm{H}_{2} \mathrm{O}$ & 3 & $215 / 220(\mathrm{~L})$ & $-21.7 /-23$ \\
Quartz & grs & secondary & halite- $\mathrm{H}_{2} \mathrm{O}$ & 3 & $290 / 300(\mathrm{~L})$ & \\
Beryl I & cgg & pseud sec. & $\mathrm{H}_{2} \mathrm{O}-\mathrm{CO}_{2}$ & 12 & $368 / 548(\mathrm{~V})$ & $-23.3 /-24.5$ \\
Beryl II & cgg & primary & $\mathrm{H}_{2} \mathrm{O}$ & 13 & $252 / 363(\mathrm{~V})$ & $-21.3 /-23.4$ \\
Beryl II & cgg & pseud sec. & $\mathrm{H}_{2} \mathrm{O}$ & 1 & $363(\mathrm{~V})$ & -21.3 \\
Fluorite & hydr. vein & pseud sec. & $\mathrm{H}_{2} \mathrm{O}$ & 11 & $163 / 170(\mathrm{~L})$ & -21 \\
Fluorite & hydr. vein & secondary & $\mathrm{H}_{2} \mathrm{O}$ & 2 & $157 / 159(\mathrm{~L})$ & -24 \\
\hline
\end{tabular}

pg, porphyritic granite; mg, marginal pegmatite (stockscheider); grs, greisen; cgg, coarse-grained biotite granite; hydr. vein, hydrothermal vein; n, number of inclusions measured; *, ranges; $\mathrm{H}_{2} \mathrm{O}$, low saline aqueous inclusion; halite- $\mathrm{H}_{2} \mathrm{O}$, halite-bearing aqueous inclusion; $\mathrm{H}_{2} \mathrm{O}-$ $\mathrm{CO}_{2}$, low saline aqueous $\mathrm{CO}_{2}$-bearing inclusion; Th $(\mathrm{L} / \mathrm{V})$, homogenization temperature to vapor or liquid phase ( $\mathrm{L}=$ to liquid, $\mathrm{V}=$ to vapor); D, decrepitation; Tm, final melting temperatures of $\mathrm{CO}_{2}$ and $\mathrm{H}_{2} \mathrm{O}$; Ts halite, dissolution temperature of halite daughter mineral: Clath., clathrate melting temperatures; $\mathrm{Te}$ (ice), apparent eutectic melting temperature of ice.

ing temperatures of 8.5 to $10^{\circ} \mathrm{C}$ and are characterized by relatively regular morphology. They are $30-100 \mu \mathrm{m}$ in size, and the volumetric proportion of the $\mathrm{CO}_{2}$ phase varies between 70 and $90 \mathrm{vol} \%$. The presence of low density $\mathrm{CO}_{2}(0.39-0.52 \mathrm{~g} / \mathrm{cc})$ can often be detected as a separate liquid $\mathrm{CO}_{2}$ phase at room temperature (Fig. 5d) and as solid $\mathrm{CO}_{2}$ (i.e. clathrate) at low temperatures. Homogenization of the inclusions to the vapor phase occurs at temperatures between 330 and $550^{\circ} \mathrm{C}$.

\section{DISCUSSION}

Although fluid inclusions sampled from different pegmatites and hydrothermal minerals are expected to have individually evolved hydrothermal systems, it is thought that some general conclusions concerning the fluid evolution of the GSS can be made by combining the data.

Experimental studies by Webster and Rebbert (1997) show that retrograde boiling of an aqueous fluid can produce brines and vapor rich $\left(\mathrm{CO}_{2}\right)$ phases at low pressure, e.g. 500 bar. Based on the fluid inclusion data presented in Table 1 and Figures 4 and 6 , it is suggested that the three fluid inclusions types described can be derived from a common, late magmatic parental fluid phase. Spatial association of type 2 halite-bearing $\mathrm{H}_{2} \mathrm{O}( \pm$ $\mathrm{CO}_{2}$ ) inclusions and type $3 \mathrm{H}_{2} \mathrm{O}-\mathrm{CO}_{2}$ inclusions, which coexist in the same crystal, suggests a common origin of the corresponding fluids. Interpreted in the $\mathrm{H}_{2} \mathrm{O}-\mathrm{NaCl}$ system (Fig. 6), the microthermometric data are consistent with the hypothesis of boiling to generate both type 1/type 3 low-salinity and type 2 high-salinity fluids. Boiling would have occurred at ca. $450^{\circ} \mathrm{C}$ under a low pressure of ca. 400 bar, i.e. under shallow depth conditions, from either type $1 \mathrm{H}_{2} \mathrm{O}\left( \pm \mathrm{CO}_{2}\right)$ inclusions of intermediate salinity (ca. 13 eq. wt\% $\mathrm{NaCl}$ ) or from a hypothetical high-temperature fluid of intermediate salinity. Pressure drop, probably necessary to generate boiling of a magmatic fluid from a shallow-level granite, is generally associated with hydraulic fracturing (e.g. Burnham 1979). 


\begin{tabular}{|c|c|c|c|c|c|c|}
\hline Tm-ice* & Ts-halite* & wt. $\% \mathrm{NaCl}$ eqv.* & $\mathrm{Tm} \mathrm{CO}_{2}{ }^{*}$ & Th $\mathrm{CO}_{2} *$ & Clath.* & density $\left(\mathrm{g} / \mathrm{cm}^{3}\right)^{*}$ \\
\hline$-0.3 /-1.6$ & & $0.53 / 2.74$ & & & & $0.2-0.97$ \\
\hline$-1.8 /-3.5$ & & $3.06 / 5.7$ & & & & $0.7-0.97$ \\
\hline & $85 / 160$ & $27 / 29$ & & & & 1,12 \\
\hline$-10,4$ & & 14.4 & & & & 1 \\
\hline & $127 / 136$ & $28 / 26$ & & & & 0,91 \\
\hline & 120 & 25 & & & & $\begin{array}{l}1 \\
0.92\end{array}$ \\
\hline & & $6 / 10$ & -56.6 & $300(\mathrm{D})$ & $4.4 / 7.6$ & $0.41-0.91$ \\
\hline-2.2 & & 3,7 & & & & \\
\hline-0.5 & & 0,88 & -56 & $-3.2 /-5.5(\mathrm{~V})$ & & $0.14-0.68$ \\
\hline $\begin{array}{l}-3 \\
0.54\end{array}$ & & $\begin{array}{l}5 \\
4.2 / 7.8\end{array}$ & -56.7 & & $8.8 / 10$ & $0.09-0.88$ \\
\hline & $188 / 196$ & $\begin{array}{l}27 / 31 \\
20 / 4.8\end{array}$ & $\begin{array}{l}-56.7 \\
-56.3 /-57\end{array}$ & $360 / 550(\mathrm{~V})$ & $8.5 / 10$ & $\begin{array}{l}0.92 \\
0.14-0.7\end{array}$ \\
\hline$-5.6 /-10.2$ & & $8.68 / 14.15$ & & & & \\
\hline$-5.7 /-7.5$ & $180 / 192$ & $\begin{array}{l}9.81 / 11.1 \\
27 / 28\end{array}$ & & & & \\
\hline $\begin{array}{l}-2 / 2 \\
-7.0 /-7.7 \\
-4.7\end{array}$ & & $\begin{array}{l}03 / 3.39 \\
10.5 / 11.3 \\
7.45\end{array}$ & $-56.6 /-41$ & $-20 /-34(\mathrm{~V})$ & & $\begin{array}{l}0.3-9 \\
0.75-0.8\end{array}$ \\
\hline$-0.5-1$ & & $0.88 / 1.74$ & & & & 0.9 \\
\hline 0 & & 0 & & & & 0.9 \\
\hline
\end{tabular}

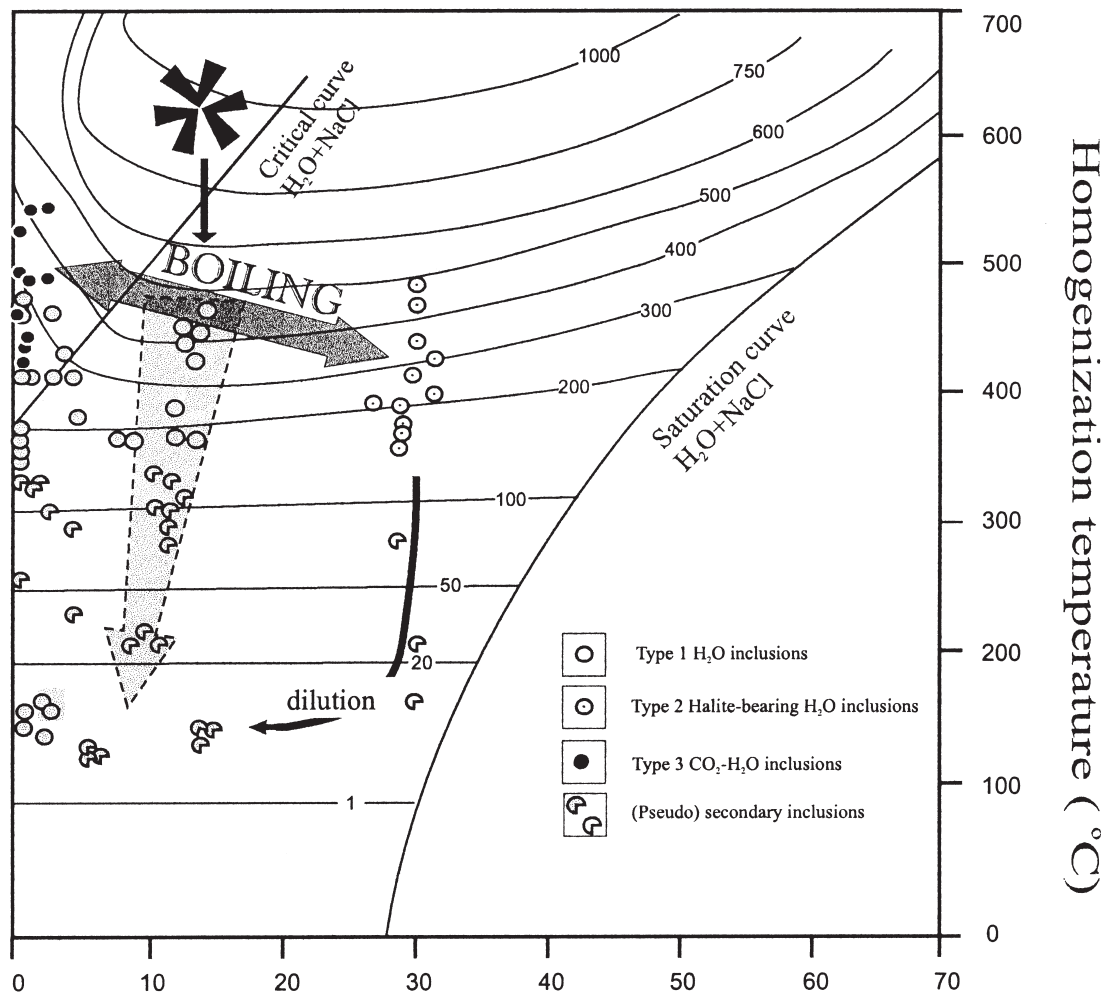

Fig. 6. Homogenization temperature vs. salinity diagram with isobaric curves for the system $\mathrm{H}_{2} \mathrm{O}-\mathrm{NaCl}$. The hypothetical magmatic fluid (star) separated from the granitic melt, which subsequently underwent second boiling (separation of $\mathrm{H}_{2} \mathrm{O}-\mathrm{CO}_{2}$ vapour and aqueous liquid). Inclusions within the stippled arrow show the fluid evolution in beryl of a greisen vein. The critical and halite saturation curves are from Sourirajan and Kennedy (1962). 


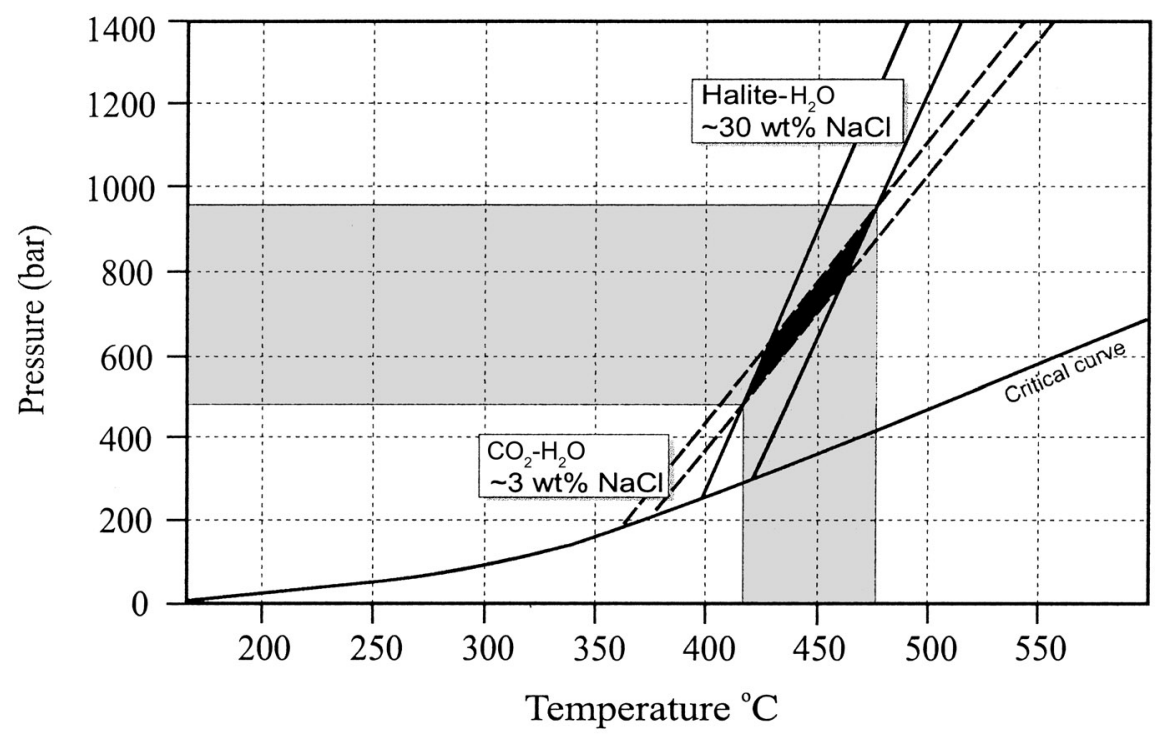

Fig. 7. Average isochores calculated from coeval $\mathrm{CO}_{2}-$ $\mathrm{H}_{2} \mathrm{O}$ and halite $-\mathrm{H}_{2} \mathrm{O}\left( \pm \mathrm{CO}_{2}\right)$ inclusions in a quartz crystal from the marginal stockscheider. Shaded areas give an estimate of fluid trapping temperatures and pressures.

The origin of the $\mathrm{CO}_{2}$ phase present in some of the inclusions is not clear. It could have a magmatic origin, however, it can also be suggested that interaction between circulating magmatic fluids of the stock and the surrounding country rock, which includes graphite-bearing carbonates, could have liberated $\mathrm{CO}_{2}$. This seems probable because $\mathrm{CO}_{2}$-bearing inclusions occur almost exclusively within minerals of the marginal stockscheider. Furthermore, the restricted occurrence of tourmaline (schorl) in the marginal stockscheider - granites of the GSS are free of boron mineralization - can be taken as evidence that fluid interaction between the stock and tourmaline-bearing country rock must have occurred.

Typically, pseudosecondary type $2 \mathrm{H}_{2} \mathrm{O}\left( \pm \mathrm{CO}_{2}\right)$ inclusions show a general decrease in salinity $(\sim 28$ to $<1$ eq. $\mathrm{wt} \% \mathrm{NaCl}$ ) with decreasing temperature from 300 to $170^{\circ} \mathrm{C}$. Although no stable isotope data of the fluids are available, it is suggested that these pseudosecondary fluid inclusions record a dilution trend (Fig. 6). That is, the saline magmatic fluid was mixed with cooler and less saline meteoric fluids.

\section{Estimates of pressure}

Despite the problems and limitations of the method of intersecting isochores (e.g. Roedder 1984), it may provide some clues for the trapping P-T conditions of the observed fluids. Assuming that type 2 halite-bearing $\mathrm{H}_{2} \mathrm{O}\left( \pm \mathrm{CO}_{2}\right)$ and type 3 mixed $\mathrm{H}_{2} \mathrm{O}-\mathrm{CO}_{2}$ fluid inclusions are contemporaneous, as suggested by their coexistence and mode of occurrence in various crystals (see Fig. 5e), and knowing the positions of the isochores, the intersecting isochores of both fluid types yield a P-T range between ca. 500 bar at $420^{\circ} \mathrm{C}$ and 900 bar at $470^{\circ} \mathrm{C}$ (Fig. 7).

The fluid trapping pressure appears to decrease with decreasing temperature. Typically, pseudosecondary inclusions reflect low trapping temperatures and pressures from 150 bar at $350^{\circ} \mathrm{C}$ to $\sim 10$ bar at $175^{\circ} \mathrm{C}$. The observed decrease in pressure suggests either rapid erosion of overlying rock or hydraulic fracturing of the host rock (i.e. pressure fluctuations).

\section{Hydraulic fracturing and mineralization}

It is generally believed that hydraulic fracturing, which occurs when the internal volatile pressure of a crystallizing body exceeds the confining lithospheric pressure, provides fractures for the release of magmatic fluids (Burnham 1979). Under certain temperature, $\mathrm{pH}$ and $\mathrm{fO}_{2}$ conditions, ore-bearing magmatic fluids will deposit metals along these fracture zones (Linnen 1998). 
In the GSS, evidence of hydraulic fracturing (i.e. hydrothermal brecciation) is not directly observed. This could be due to either insufficient build up of volatile pressure, as would be expected in relatively anhydrous magmas or, if there were hydraulic fractures, evidence of it would have been removed during erosion of the overlying rocks. At the present level of erosion, few greisen bodies and hydrothermal veins are seen within the porphyritic granite, suggesting that within the porphyritic granite phase water-saturation was attained, and that at least locally some hydraulic fracturing occurred.

Investigation of the $\sim 200 \mathrm{~m}^{2}$ greisen body from the northern flank of the porphyritic granite shows several hydrothermal beryl and quartz vein systems. In addition, the presence of hematite-goethite veins is indicative of oxidized conditions at the time of their formation. Microthermometry measurement conducted on a beryl vein shows a progressive decrease in trapping temperatures and pressures from 470 to $330^{\circ} \mathrm{C}$, and $\sim 500$ to $30 \mathrm{bar}$, respectively, for the moderately saline pseudosecondary type $2 \mathrm{H}_{2} \mathrm{O}$ $\left( \pm \mathrm{CO}_{2}\right)$ inclusions (cf. Fig. 6). The milky-quartz veins contain too small fluid inclusions for microthermometry. Associated with the milky-quartz veins are disseminated wolframite and columbite crystals up to $1 \mathrm{~cm}$ in length. The analysis of a quartz vein using fluid inclusion decrepitometry indicates the presence of low-temperature $\left(<350^{\circ} \mathrm{C}\right)$ $\mathrm{CO}_{2}$-bearing fluid inclusions (see Fig. 3).

Based on the available fluid inclusion data from the pegmatite, hydrothermal and greisen minerals, it can be concluded that the mineralizing fluids were most likely associated with relatively oxidized, low-temperature and low-saline type $3 \mathrm{H}_{2} \mathrm{O}$ $\mathrm{CO}_{2}$ fluids, and that ore deposition probably took place in response to a drop in pressure, brought about by hydraulic fracturing.

\section{CONCLUSIONS}

The anorogenic Gross Spitzkoppe granite stock, located in the Southern Tin Zone of the Damara orogenic belt in Namibia, consists of three evolved monzogranites and has pegmatite bodies as banded marginal stockscheider and internal isolated pockets. Greisen bodies and hydrothermal veins occur within the porphyritic granite phase of the stock.

This study has shown that fluid inclusion data from pegmatite, greisen and hydrothermal minerals can provide useful information when ascertaining fluid compositions and P-T evolution paths for late- to post-magmatic fluids. It reveals the following points:

- The three fluid inclusion types are probably derived from a common, late-magmatic fluid phase similar to type $1 \mathrm{H}_{2} \mathrm{O}\left( \pm \mathrm{CO}_{2}\right)$ fluid inclusions. Fluid inclusion types 2 and 3, which often coexist in the same crystal, were most likely derived from the late-magmatic fluid, but separated during retrograde boiling in response to a drop in pressure.

- The fluid inclusion data suggest maximum trapping pressures of $\sim 450$ bar at $\sim 500^{\circ} \mathrm{C}$ for the primary fluid inclusions. Further estimates for trapping P-T conditions can be obtained from coexisting type 2 and 3 inclusions of the marginal stockscheider, based on their intersecting isochors, which yield a maximum trapping pressure of 900 bar at $470^{\circ} \mathrm{C}$.

- Fluid inclusion decrepitometry indicates an increase in fluid activity from the mediumgrained granite to the porphyritic granite of the stock. Local fluid saturation is indicated by miarolitic cavities, greisen bodies and hydrothermal veining.

- Disseminated wolframite and columbite related to the greisen quartz veins are associated with relatively low-temperature low-saline type $3 \mathrm{H}_{2} \mathrm{O}-\mathrm{CO}_{2}$ fluids, and this ore mineralization took place in response to a drop in pressure, brought about by hydraulic fracturing.

- Economically important ore mineralization is not found in the Gross Spitzkoppe stock. It is possible that the best-mineralized apical parts were eroded away from the high-level granite stock. Another possibility is that ore elements like tin were partitioned to the melt phase and mafic silicates instead of the fluid phase. This is in agreement with the rather high tin content of biotite. 
ACKNOWLEDGEMENTS. We wish to thank Prof. Ilmari Haapala for initiating this study and for helpful discussions. We also thank Dr. Csaba Szabo for reviewing the manuscript. This research was funded by the Academy of Finland (project number 40674) and CIMO (Centre for International Mobility), and is a contribution to IGCP Project 373 Correlation, Anatomy and Magmatic-Hydrothermal Evolution of Ore-Bearing Felsic Igneous Systems in Eurasia.

\section{REFERENCES}

Bodnar, R.J. 1993. Revised equation and table for determining the freezing point depression of $\mathrm{H}_{2} \mathrm{O}-\mathrm{NaCl}$ solutions. Geochemica et Cosmochimica Acta 57, 683684.

Burlinson, K. 1988. An instrument for fluid inclusion decrepitometry and examples of its application. Bulletin de Minèralogie 111, 267-278.

Burlinson, K. 1991. Decrepitation in gold exploration. A case history from the Cotan prospect, N.T.J. Journal of Geochemical Exploration 42, 143-156.

Burnham, C.W. 1979. Magmas and hydrothermal fluids. In: Barnes, H.L (ed.), Geochemistry of Hydrothermal Ore Deposits, $2^{\text {nd }}$ ed., London: Wiley, 71-136.

Frindt, S. 1997. Petrography and geochemistry of the Gross Spitzkoppe igneous complex. Unpublished M.Sc. Thesis, University of Helsinki. 88p.

Frindt, S. \& Haapala, I. 1999. Petrography and geochemistry of the Mesozoic Gross Spitzkoppe granite complex in western Namibia - an example of granite magmatism Related to continental rifting. Fourth Hutton Symposium on the Origin of Granites and Related Rocks. Clermont-Ferrand, France, September 1999. Abstract volume.

Frindt, S. \& Poutiainen, M. 1999. A fluid inclusion study of minerals from pegmatites, greisens and hydrothermal veins in the anorogenic Gross Spitzkoppe granite complex, western Namibia. Fourth Hutton Symposium on the Origin of Granites and Related Rocks. Clermont-Ferrand, France, September 1999. Abstract volume.

Frindt, S. 2000. Greisen mineralization of the Gross Spitzkoppe granite stock, western Namibia. Rapakivi Granites and Associated Mineralization. IGCP Project 373 Field Conference in southern Finland, July 3-7, 2000, Excursion Guide and abstracts.

Linke, W.F. 1965. Solubilities of inorganic and metal-organic compounds. $4^{\text {th }}$ ed. Washington D.C: American Chemical Society. 1914 p.

Linnen, R.L. 1998. Depth of emplacement, fluid provenance and metallogeny in granitic terranes: a comparison of western Thailand with other tin belts. Mineralium Deposita 33, 461-476.
Martin, H. 1965. The Precambrian geology of South-West Africa and Namaqualand. Precambrian Research Unit, University of Cape Town. 159 p.

Mavrogenes, J.A., Bodnar, R.J., Graney, J.R., McQueen, K.G. \& Burlinson, K. 1995. Comparison of decrepitation, microthermometric and compositional characteristics of fluid inclusions in barren and auriferous mesothermal quartz veins of the Cowra Creek Gold District, New South Wales, Australia. Journal of Geochemical Exploration 54, 167-175.

Ollila, J.T. 1987. Genetic aspects of Sn, Li, Be, Nb-Ta pegmatites and $\mathrm{Sn}-\mathrm{W}$ vein deposits of the Damaraland orogeny, Namibia. Bulletin of the Geological Society of Finland 59, Part 1, 21-34.

Pearce, J.A., Harris, N.B.W. \& Tindle, A.G. 1984. Trace element discrimination diagrams for the tectonic interpretation of granitic rocks. Journal of Petrology 25, 956983.

Pirajno, F. \& Schlögel, H.U. 1987. The alteration-mineralization of the Krantzberg tungsten deposit, South West Africa/Namibia. South African Journal of Geology 90, 499-508.

Roedder, E. 1981. Origin of fluid inclusions and changes that occur after trapping. In: Hollister, L.S. \& Crawford, M.L. (eds.) Short course in fluid inclusions: applications to petrology. Mineralogical Association of Canada. 304 p.

Roedder, E. 1984. Fluid inclusions. Reviews in Mineralogy $12.644 \mathrm{p}$.

Scott, H.S. 1948. The decrepitation method applied to minerals with fluid inclusions. Economic Geology 43, 637645.

Sterner, M.S. \& Bodnar, R.J. 1984. Synthetic fluid inclusions in natural quartz: 1 Compositional types synthesized and applications to experimental geochemistry. Geochemica et Cosmochimica Acta 48, 2659-2668.

Sourirajan, S. \& Kennedy, G.C. 1962. The system $\mathrm{H}_{2} \mathrm{O}-$ $\mathrm{NaCl}$ at elevated temperatures and pressures. American Journal of Science 260, 115-141.

Steven, N.M. 1993. A study of epigenetic mineralisation in the central zone of the Damara orogen, Namibia, with special reference to gold, tungsten, tin and rare earth elements. Geological Survey of Namibia, Memoir 16. 161 p.

Trumbull, R.B., Schmitt, A., Frindt, S., Emmerman, R. \& Haapala, I. 2000. Cretaceous anorogenic granites and silicic volcanics at the passive margin of Namibia. $31^{\text {st }}$ International Geological Congress, Rio de Janeiro, Brazil, Abstract Volume CD.

Wagener, G.F. 1989. Systematic variation in the tin content of pegmatites in western central Namibia. Journal of Geochemical Exploration 34, 1-19.

Webster, J.D. \& Rebbert, C.R. 1997. Experimental investigation of $\mathrm{H}_{2} \mathrm{O}$ and $\mathrm{Cl}^{-}$solubilities in F-enriched silicate liquids; implications for volatile saturation of topaz rhyolite magmas. Contributions to Mineralogy and Petrology 132, 198-207. 